\title{
The role of log jams and exceptional flood events in mobilizing coarse particulate organic matter in a steep headwater stream
}

\author{
M. Jochner ${ }^{1,2}$, J. M. Turowski ${ }^{3,1}$, A. Badoux ${ }^{1}$, M. Stoffel ${ }^{4,5}$, and C. Rickli ${ }^{1}$ \\ ${ }^{1}$ WSL Swiss Federal Institute for Forest, Snow and Landscape Research, 8903 Birmensdorf, Switzerland \\ ${ }^{2}$ Forest Ecology, Institute of Terrestrial Ecosystems, Department of Environmental Systems Science, ETH \\ Zurich, 8092 Zurich, Switzerland \\ ${ }^{3}$ Helmholtz Centre Potsdam, GFZ German Research Centre for Geosciences, 14473 Potsdam, Germany \\ ${ }^{4}$ Dendrolab.ch, Institute of Geological Sciences, University of Bern, 3012 Bern, Switzerland \\ ${ }^{5}$ Institute for Environmental Sciences, University of Geneva, 1227 Carouge, Switzerland
}

Correspondence to: M. Jochner (matthias.jochner@usys.ethz.ch)

Received: 12 February 2015 - Published in Earth Surf. Dynam. Discuss.: 26 February 2015

Revised: 7 May 2015 - Accepted: 26 May 2015 - Published: 14 July 2015

\begin{abstract}
Coarse particulate organic matter (CPOM) fulfills important functions in the physical and ecological system of a stream. CPOM delivery to and export from the stream has implications for the stream's morphology and sediment transport capacity as well as the energy budget and food availability. Export rates of CPOM from mountain catchments have been observed to strongly increase with rising discharge, but the mechanism leading to this strong relationship is unclear. Here, we show that log jams in the Erlenbach, a steep headwater stream in the Swiss Prealps, are an effective barrier for the transport of CPOM pieces, and thus become sites of storage of large quantities of material over time. Exceptional discharge events with return periods exceeding 20 years play a dual role in CPOM transport in the Erlenbach. First, they appear to destroy existing log jams, releasing the stored material (wood and sediment). Second, they intensify channel-hillslope coupling, thereby recruiting new logs to the channel, around which new jams can form. This allows for the formulation of a new, fully episodic endmember in a four-end-member model of CPOM dynamics of steep mountain streams based on wood delivery and export.
\end{abstract}

\section{Introduction}

Coarse particulate organic matter (CPOM) in streams is typically defined as organic material with a diameter larger than $1 \mathrm{~mm}$, and thus encompasses a wide range of different types and sizes, from leaves and twigs to wood fragments and entire trees (Naiman and Sedell, 1979; Bilby and Likens, 1980). CPOM is an important component both of the physical and the ecological system of the stream. It affects stream morphology and alters channel roughness, and therefore flow velocity and sediment transport (Bilby and Ward, 1989). When entering the stream, organic matter is considered to be the main source of energy in headwater ecosystems and provides food, shelter, and variable habitats (Fisher and Likens,
1973; Harmon et al., 1986). The largest size classes of CPOM are known as large woody debris (LWD), comprising pieces longer than $1 \mathrm{~m}$ (e.g., Abbe and Montgomery, 2003; Wohl and Jaeger, 2009). LWD specifically affects stream morphology, habitat and riverine carbon, and nutrient storage by forming log jams that act as barriers for sediment movement, and that are sites of energy dissipation (Wohl and Beckman, 2012; Beckman and Wohl, 2014). Thus, log jams create sites with both lower and higher flow velocities than the average of the stream, and develop habitats for different life stages of both fish and invertebrates (Wohl, 2013).

CPOM is recruited to the stream by various processes, including litter fall, wind throw, gravitational movements of the banks, and natural dieback of trees. Once in the stream, 
CPOM is degraded by various physical, chemical, and biological processes, or can be flushed out by fluvial processes. CPOM leaving the catchment represents a loss of nutrients and energy to the stream ecosystem (Fisher and Likens, 1973; Naiman and Sedell, 1979; Webster et al., 1999), and, in case of LWD, can lead to an increased hazard downstream (Comiti et al., 2006; Ruiz-Villanueva et al., 2014). It is known that CPOM export from a catchment strongly depends on discharge (e.g., Bormann et al., 1969; Fisher and Likens, 1973; Wallace et al., 1995; Iroumé et al., 2015). From detailed short-term measurements over a range of discharges, Turowski et al. (2013a) found that $90 \%$ of the total CPOM load of the Erlenbach, a prealpine mountain stream in Switzerland, was exported by floods with return periods of $>5$ years. Here, CPOM export rates increase by a factor of more than 30000 upon a 10-fold increase in discharge. The results from Fisher and Likens (1973) and Wallace et al. (1995) indicate similarly strong relationships between CPOM export and discharge; however, the former derived their data from a very small catchment and the latter did not have point measurements, but integrated over entire events. Still, most conceptual models of wood dynamics formulated in studies of low-order streams similar to the Erlenbach and larger streams suggest more continuous export rates and seemingly do not apply to our study area (Hyatt and Naiman, 2001; O'Connor et al., 2003; Wohl et al., 2012; Wohl, 2013). The concept of May and Gresswell (2003), derived from the data on a steep mountain stream, postulates episodic export of larger fractions of CPOM, although in conjunction with debris flow events rather than fluvial transport.

In the present contribution, we investigate the physical mechanisms behind the strong dependence of CPOM export rates and discharge in the Erlenbach by introducing tracer $\operatorname{logs}$ to the stream and tracking them over a series of elevated discharge events. Wallace et al. (1995) observed a strong increase in CPOM export after log jam failures. We thus hypothesize that log jams play a crucial role in CPOM transfer; by mapping all log jams in the study reach of the tracer experiment, we demonstrate that they indeed represent effective barriers for transport. We elucidate the role of exceptional events in log jam stability by employing dendrochronological analyses, and we propose a conceptual model of wood dynamics in headwater streams.

\section{Study site}

The Erlenbach is a small tributary of the Alp river and is located in the Alptal valley in the Swiss Prealps (Fig. 1, Table 1). With a catchment area of $0.7 \mathrm{~km}^{2}$ and a mean channel slope of $18 \%$, its elevation ranges from 1100 to $1655 \mathrm{~m}$ a.s.l. (Badoux et al., 2012). Discharge and meteorological variables are recorded at $10 \mathrm{~min}$ intervals, while sediment export can be monitored with various types of equipment (Badoux

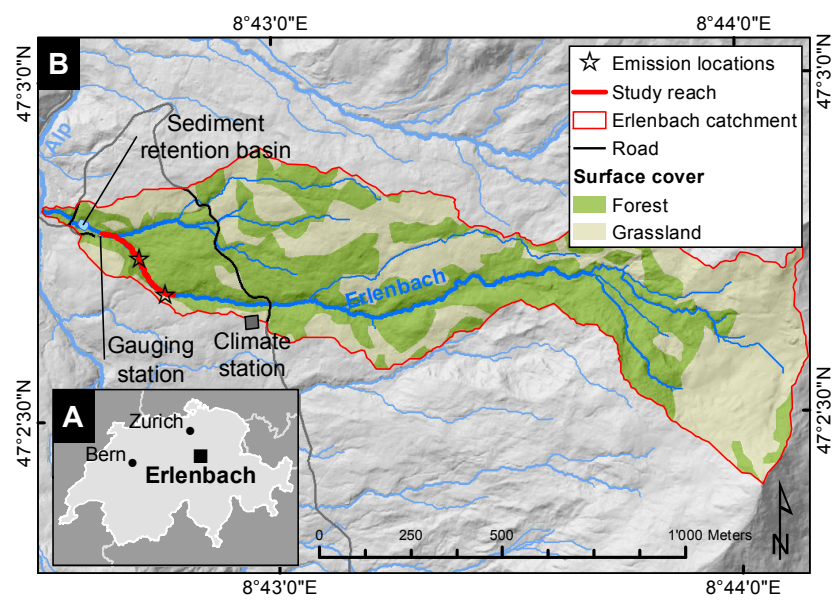

Figure 1. Overview map of the Erlenbach catchment showing (a) its position within Switzerland as well as (b) its topography, instrumentation features and the study reach (cf. Fig. 4). Data source: DTM-AV ${ }^{\circledR} 2014$ Swiss Federal Directorate of Cadastral Surveying (DV033531).

Table 1. Catchment characteristics of the Erlenbach stream in Switzerland (cf. Turowski et al., 2009; Badoux et al., 2012).

\begin{tabular}{ll}
\hline Catchment parameter & Value \\
\hline Basin area $\left(\mathrm{km}^{2}\right)$ & 0.7 \\
Elevation range (m a.s.1.) & $1110-1655$ \\
Average channel gradient $(\%)$ & 18 \\
Mean annual precipitation sum 1981-2009 (mm) & 2290 \\
Mean annual temperature 1981-2009 $\left({ }^{\circ} \mathrm{C}\right)$ & 4.5 \\
Forest cover $(\%)$ & 39 \\
Wetland and grassland $(\%)$ & 61 \\
Unvegetated land $(\%)$ & $\ll 1$ \\
\hline
\end{tabular}

et al., 2012; Rickenmann et al., 2012; Turowski et al., 2013b). The channel shows a pronounced step-pool morphology with some cascading and riffle reaches and has an average bankfull channel width of $3.7 \mathrm{~m}$ (Molnar et al., 2010). Its banks are prone to hillslope creep and actively supply the channel with sediment and organic matter, including wood of a wide range of sizes (Schuerch et al., 2006; Turowski et al., 2009, 2013a). There have been no signs of debris flow occurrence in the channel, and sediment transport was observed to be fluvial even under the highest discharges (Turowski et al., 2009). Around $40 \%$ of the catchment area is covered by multi-level subalpine forest, dominantly Norway spruce (Picea abies) and silver fir (Abies alba), and the remaining $60 \%$ of the area is grass and wetlands (Burch, 1994). CPOM export from the Erlenbach was assessed in detail by Turowski et al. (2013a) by measuring transport rates and dry masses of organic matter heavier than $0.1 \mathrm{~g}$ leaving the catchment. However, their study did not focus on the processes within the stream leading to the observed rating curve. 
In the recent past, two exceptional discharge events occurred in the catchment after intense rain storms. The first one occurred in June 2007, featuring the highest discharge recorded to date with a peak runoff of $14.6 \mathrm{~m}^{3} \mathrm{~s}^{-1}$ and an estimated return period of around 50 years (Turowski et al., 2013b; Turowski et al. 2009). In August 2010, a second event occurred with a peak runoff of $10.9 \mathrm{~m}^{3} \mathrm{~s}^{-1}$, corresponding to a return period of approximately 20 years (Turowski et al., 2013b), which was the last exceptional event before the present study was conducted.

\section{Methods}

We mapped LWD in a $320 \mathrm{~m}$ long study reach of the Erlenbach, focusing on log jams (Fig. 1). A log jam was defined as an accumulation of coarse wood deposited against or around at least one initial key piece of LWD (Warren et al., 2009). To determine the position of the log jams within the channel and for an analysis of deposition locations of the belowmentioned tracer logs, the perimeters of the jams were surveyed with an electronic total station, and their extent and height were recorded using a measuring tape (cf. Wohl and Beckman, 2012). To check for a relationship between residence times of the jams' key pieces and log jam size, volumes and dry masses of the pieces of wood longer than $1 \mathrm{~m}$ stored in $\log$ jams were approximated by measuring their length and diameter in the field (cf. May and Gresswell, 2003), and by assuming a cylindrical shape and a dry wood density of $410 \mathrm{~kg} \mathrm{~m}^{-3}$, which is characteristic for P. abies (Gryc et al., 2011). The total combined volume of pieces shorter than $1 \mathrm{~m}$ was estimated visually with the help of a measuring tape. This estimation made up for $29 \%$ of the total volume of all log jams. Log jam step heights were derived from long profile measurements (Turowski et al., 2013b). The analyses were conducted in July and August 2012.

To investigate the mechanisms behind transport and storage of CPOM within the Erlenbach channel, a population of 236 cylindrical logs (Fig. 2) were tagged with radio frequency identification (RFID) transponders, a technique that has successfully been employed to monitor bedload (Lamarre et al., 2005; Schneider et al., 2010, 2014) and woody debris (MacVicar et al., 2009; Schenk et al., 2013; Ravazzolo et al., 2015). The RFID glass transponders we used were $3.12 \mathrm{~cm}$ long, $0.38 \mathrm{~cm}$ in diameter, emitting at $134.2 \mathrm{kHz}$ frequency, and were glued into holes drilled into the tracer logs. The tracers were divided in four classes with approximate lengths of $10,20,50$, and $100 \mathrm{~cm}$. The lengths were chosen as a compromise between log size and potential log mobility, suitable for our study period covering only one summer season. Longer pieces would have rarely moved in common discharge events during the study period. For shorter pieces, it would not have been possible to equip them with RFID transponders. The size distribution of the tracers did not cover the whole size range of CPOM transported by

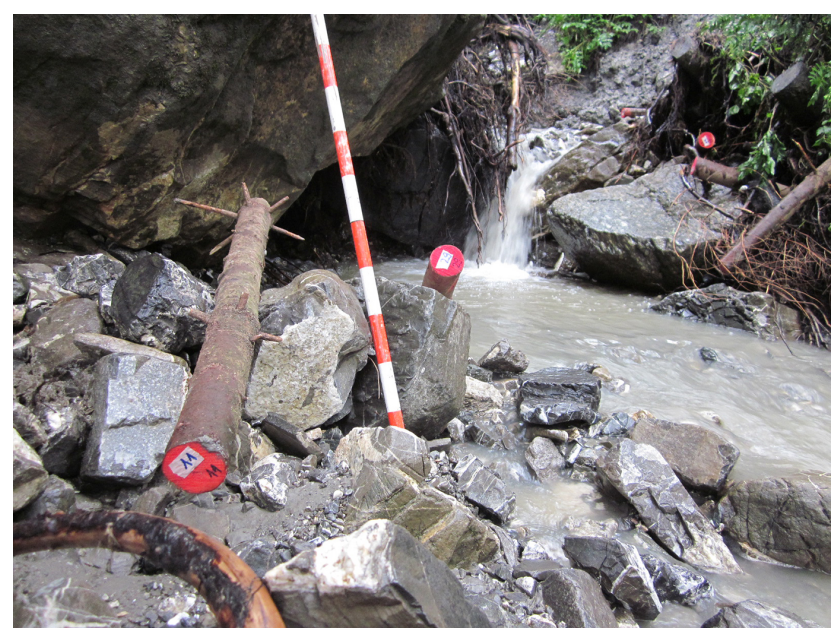

Figure 2. Tracer log with length $100 \mathrm{~cm}$ lying loose on the channel surface in the foreground. Other tracer logs are visible in the background.

the Erlenbach stream. However, our study analyses the relative mobility of single size classes in and out of log jams and therefore the size distribution is suitable for our purpose. The initial population of tracer logs was emitted in the stream in June 2012, and the positions of the logs were surveyed six times after rainfall events until October 2012 (Fig. 3). Tracer logs that left the study reach after being mobilized and could be recovered in the sediment retention basin were re-emitted in July, August, and September 2012 (Fig. 3). Two locations for the emission of the tracers were chosen because of the relative absence of obstacles, steps, and pools compared to most other channel reaches and were hypothesized to enhance the probability of a first displacement. The tracer pieces were spread out along approximately $5-10 \mathrm{~m}$ of the thalweg axis without trying to mimic a natural deposition. It was assumed that after an initial mobilization during a flood event, tracers would be deposited in a natural way. During this time 11 events with discharges exceeding $0.5 \mathrm{~m}^{3} \mathrm{~s}^{-1}$ were recorded (Fig. 3, Table 2). Peak discharge during the entire study period was $1.25 \mathrm{~m}^{3} \mathrm{~s}^{-1}$, a flood size that typically occurs several times a year in the Erlenbach.

To obtain approximate residence times of the logs stored in the jams, tree-ring analysis was conducted using the methodology described by Stoffel and Corona (2014). Cross-dating deadwood with a reference chronology of living trees gives the calendar year of the trees' terminal ring and therefore the date of their dieback. A number of 30 undisturbed P. abies in the vicinity of the Erlenbach channel were sampled for the reference chronology, showing a series intercorrelation of 0.471 . The sampling of logs stored within the dams was limited to conifers since the catchment is covered by subalpine forest with only $10-15 \%$ deciduous trees. A minimum diameter of $30 \mathrm{~cm}$ has been defined as necessary to conduct reliable age dating (Hyatt and Naiman, 2001). Too 
Table 2. Parameters of elevated discharge events above $0.5 \mathrm{~m}^{3} \mathrm{~s}^{-1}$ in the Erlenbach that occurred between 22 June to 25 October 2012 . This time period corresponds to the study period of the tracer experiment. $Q_{\max }$ is the peak discharge of each event, $Q_{\text {eff }}$ is the effective volume of water that passed the gauge during periods with a discharge above $0.5 \mathrm{~m}^{3} \mathrm{~s}^{-1}$.

\begin{tabular}{llclr}
\hline Discharge event & Date & Duration [h:min] & $Q_{\max }\left[\mathrm{m}^{3} \mathrm{~s}^{-1}\right]$ & $Q_{\text {eff }}\left[\mathrm{m}^{3}\right]$ \\
\hline 1 & 25 Jun 2012 & $3: 00$ & 0.86 & 8077 \\
2 & 16 Aug 2012 & $2: 40$ & 0.78 & 6779 \\
3 & 25 Aug 2012 & $3: 20$ & $1.21 / 0.91^{*}$ & 10497 \\
4 & 1 Sep 2012 & $0: 20$ & 0.54 & 952 \\
5 & 12 Sep 2012 & $8: 40$ & $1.25 / 1.17^{*}$ & 21045 \\
6 & 19 Sep 2012 & $2: 10$ & 0.81 & 5705 \\
7 & 26 Sep 2012 & $0: 10$ & 0.53 & 317 \\
8 & 27 Sep 2012 & $2: 10$ & 0.96 & 6445 \\
9 & 7 Oct 2012 & $2: 20$ & 0.97 & 6425 \\
10 & 9 Oct 2012 & $5: 00$ & $0.86 / 1.16^{*}$ & 13951 \\
11 & 10 Oct 2012 & $4: 30$ & 0.74 & 11930 \\
\hline
\end{tabular}

* Event with two discharge peaks.

Table 3. Log jam (LJ) characteristics and tracer log point densities for the log jam perimeters in the Erlenbach.

\begin{tabular}{|c|c|c|c|c|c|c|c|c|c|c|}
\hline $\begin{array}{l}\text { Log jam } \\
\text { number }\end{array}$ & $\begin{array}{l}\text { Area } \\
\left(\mathrm{m}^{2}\right)\end{array}$ & $\begin{array}{c}\text { Step } \\
\text { height }^{\mathrm{a}} \\
(\mathrm{m})\end{array}$ & $\begin{array}{l}\text { Volume }^{b} \\
\left(\mathrm{~m}^{3}\right)\end{array}$ & $\begin{array}{r}\text { Dry } \\
\text { mass } \\
(\mathrm{kg})\end{array}$ & $\begin{array}{c}\text { Mean tracer } \\
\text { density } \\
\left(1 \mathrm{~m}^{-2}\right)\end{array}$ & $\begin{array}{c}\text { Max. tracer } \\
\text { density } \\
\left(1 \mathrm{~m}^{-2}\right)\end{array}$ & $\begin{array}{c}\text { Min. tracer } \\
\text { density } \\
\left(1 \mathrm{~m}^{-2}\right)\end{array}$ & $\begin{array}{l}\text { Number of } \\
\text { dated logs }\end{array}$ & $\begin{array}{c}\text { Mean age } \\
\text { of } \operatorname{logs}^{\mathrm{d}} \\
(\mathrm{yr})\end{array}$ & $\begin{array}{r}\text { Mean } \\
\text { residence } \\
\text { time }^{\mathrm{d}}(\mathrm{yr})\end{array}$ \\
\hline LJ1 & 30.0 & 1.4 & 7.98 & 3272 & 0.05 & 0.11 & 0.00 & 2 & 58.0 & 11.5 \\
\hline $\mathrm{LJ} 2$ & 26.8 & 1.1 & 1.41 & 578 & 0.14 & 0.25 & 0.00 & 2 & 71.0 & 1.5 \\
\hline LJ3 & 40.0 & 0.4 & 1.50 & 614 & 0.80 & 1.70 & 0.00 & 4 & 98.2 & 2.3 \\
\hline LJ4 & 37.2 & 1.9 & 2.12 & 869 & 0.23 & 0.46 & 0.00 & 2 & 72.0 & 4.5 \\
\hline LJ5 & 14.5 & 1.0 & 0.65 & 266 & 0.50 & 0.78 & 0.07 & 2 & 90.5 & 5.0 \\
\hline LJ6 & 6.4 & 1.1 & 0.51 & 211 & 0.40 & 0.53 & 0.25 & 2 & 94.0 & 3.0 \\
\hline LJ7 & 14.5 & 0.7 & 1.55 & 636 & 0.68 & 0.95 & 0.11 & 1 & 37.0 & 5.0 \\
\hline LJ8 & 60.0 & 1.6 & 5.70 & 2335 & 0.83 & 2.30 & 0.00 & 3 & 55.3 & 3.7 \\
\hline LJ9 & 17.7 & 2.1 & 3.76 & 1542 & 0.50 & 0.71 & 0.14 & 2 & 72.5 & 4.5 \\
\hline
\end{tabular}

a Steps and pools derived from long profile using the algorithm proposed by Zimmermann et al. (2008).

$\mathrm{b}$ Based on measurement of length and diameter of woody debris pieces stored in log jams longer than $1 \mathrm{~m}$ and assuming a cylindrical shape of the pieces.

c Calculated from volume assuming a dry wood density of $410 \mathrm{~kg} \mathrm{~m}^{-3}$.

${ }^{\mathrm{d}}$ Derived from cross-dating deadwood with a reference tree ring chronology of 30 living trees standing in the vicinity of the Erlenbach stream channel.

few broad-leaved trees of the appropriate size were available near the stream for study, but only 2 out of 26 LWD samples in the stream were from broad-leaved trees. Thus, the survey yielded a total of 24 dated logs in $9 \log$ jams, and the focus on conifers can be assumed not to bias the results. Four of the sampled logs stored in the channel had already substantially decayed or were damaged during flood events. Still, for all logs, more than half of the outermost circumference corresponded to a single tree ring, which means that the terminal ring of the last year of growth was likely present in the sample. All deadwood samples from the jams were first visually cross-dated using their increment curves and the reference chronology. Then, their accuracy was checked with the cross-dating function of the dendrochronology software TSAP-Win. Our accuracy check was based on Gleichläufigkeit (GLK), which is the percent agreement in the signs of the first differences of two time series (Kaennel and Schwein- gruber, 1995). The significance of the GLK value depends on the length of the overlap of the reference and undated time series. For example, for a 50-year overlap, a GLK of 62 is significant $(p<0.05)$. Depending on the length of the respective series we considered cross-dating successful if a significant GLK value was achieved (Lombardi et al., 2008), which was possible for all of our sampled logs. The kill date is assumed to be the year when the logs were introduced to the channel. There is a chance that trees remained outside the channel for an unknown period of time before entering the stream. Smith et al. (2013) found fragments of wood in bank landslide deposits at the Erlenbach which were ${ }^{14} \mathrm{C}$ dated to 1000 and 4000 BP. However, our assumption is based on the fact that the channel slopes are very steep and that those large, jamforming pieces of wood are unlikely to remain on the slopes above the channel for extended times or be buried like the fragments analyzed of Smith et al. (2013). 


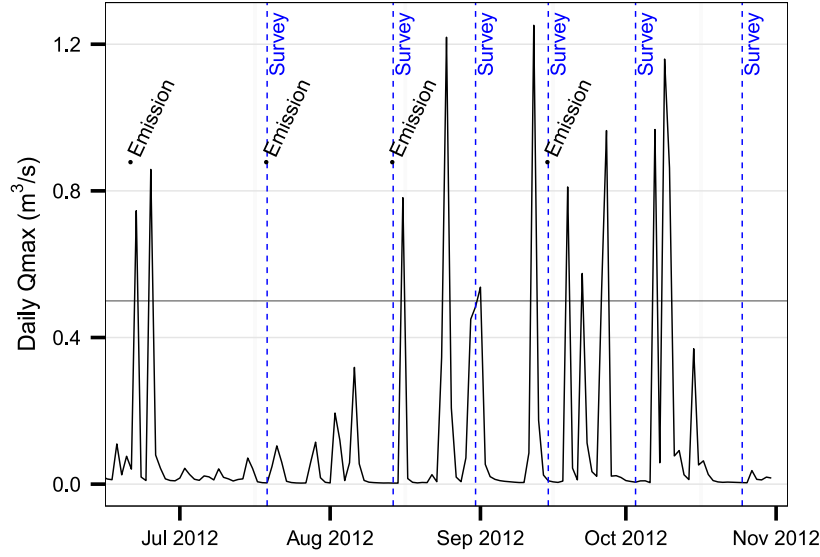

Figure 3. Daily peak discharge of the Erlenbach between 20 June and 31 October 2012 measured at the gauging station. According to Rickenmann and McArdell (2007) as well as Turowski et al. (2011), the critical discharge for the start of bedload transport amounts to approximately $0.5 \mathrm{~m}^{3} \mathrm{~s}^{-1}$ (horizontal bold black line). The dates of tracer emissions and surveys are labeled.

\section{Results}

\subsection{Log jam survey}

We identified nine log jams (LJ1 to LJ9) in the study reach (Table 3), corresponding to $2.8 \log$ jams per $100 \mathrm{~m}$ of channel or $16.7 \%$ of the study reach's bankfull channel area (Fig. 4). The values observed in this study are high, but not unusual for streams with similar characteristics and size (Kraft et al., 2011; Warren et al., 2009; Wohl and Beckman, 2012). Seven of the jams were most likely caused by a large (initial) tree that entered the stream, presumably due to bank erosion (Fig. 5b, c and d). The bank erosion either directly undercut the tree's rootwad or initiated hillslope creep that resulted in trees falling across the channel. The remaining two jams (LJ1 and LJ7) likely formed because large boulders constricted the channel (Fig. 5a). In the case of LJ7, the boulder acted as a barrier for transport, recruiting large logs from the adjacent riparian vegetation. With the exception of $\mathrm{LJ} 1$, for which the situation is not clear, the initial trees all originated from the contiguous adjacent riparian vegetation, and had not been moved far from their original growing position.

\subsection{Tracer study}

The tracer study revealed that log jams in the Erlenbach are an efficient barrier to the movement of CPOM pieces. The overall average recovery rate of tracers during all six surveys amounted to $34 \%$ with the rates of the individual surveys varying between 29 and $45 \%$. These values are similar to the rates observed in a study of bedload motion at the same site also using RFID equipment (Schneider et al., 2010, 2014). The tracer logs preferably deposited in log jams (Fig. 4), showing an average tracer density of 0.46 pieces per $\mathrm{m}^{2}$ in the perimeter of jams while the obstruction-free parts of the bankfull channel only saw 0.13 pieces per $\mathrm{m}^{2}$ over the study season. Once deposited in the perimeter of a log jam, it was very unlikely that the tracers moved further downstream during the study period (Fig. 6). Given that pieces initially inside of log jams have a median transport distance at or near zero (Fig. 6), and that this observation is valid equally for all measured size classes, it is likely that this discrepancy is also valid for sizes substantially smaller than our smallest tracers with $10 \mathrm{~cm}$ length. The observations also imply that we expect large CPOM export rates only in case of log jam destruction, i.e., when the material stored within them is released into the stream bed. This raises the question of when log jams are mobilized.

\subsection{Log jam dating}

Based on the tree-ring analysis, the residence times of jammed logs within the channel varied between 1 and 13 years with a median of 4 years (Table 3 ). Only two logs, both in LJ1, entered the stream prior to 2007 (these trees died in 1999 and 2002, respectively). The residence time of trees within the same log jam varies between zero (LJ5, with two kill dates in 2007), and 4 years (LJ6, with kill dates in 2007 and 2011). The number of trees with simultaneous kill dates varied strongly and peaked in $2007(n=7)$ and $2010(n=5)$, with decreasing numbers in the subsequent years (Fig. 7). We did not find correlations between residence time of the logs in the stream and the longitudinal position of the respective log jam within the study reach, effective jam area, log jam volume, or dry mass.

However, the input of trees to the channel is strongly related to the occurrence of exceptional discharge events. The years with the largest discharge events $(2007,2010)$ correspond to the years with the highest numbers of tree kills. More than one kill date was also observed in $2008(n=3)$ and $2011(n=2)$, i.e., in the years following exceptional discharge events.

\section{Discussion}

\subsection{Interpretation}

Observations suggest that almost all LWD that entered the study reach before the 50-year flood in June 2007 would have been removed by the exceptional event in 2007. The pieces present in the reach were thus recruited and deposited after the 2007 flood. The subsequent 20-year flood in August 2010 did not cause a complete renewal of the in-stream wood population but nonetheless did mobilize several jammed pieces. The exceptional discharge events not only led to the failure of all (2007) or some (2010) log jams, but also reactivated or intensified the LWD input, thereby promoting the formation of new log jams. In the Erlenbach, these events have effects on stream dynamics and bedload transport that can last several 


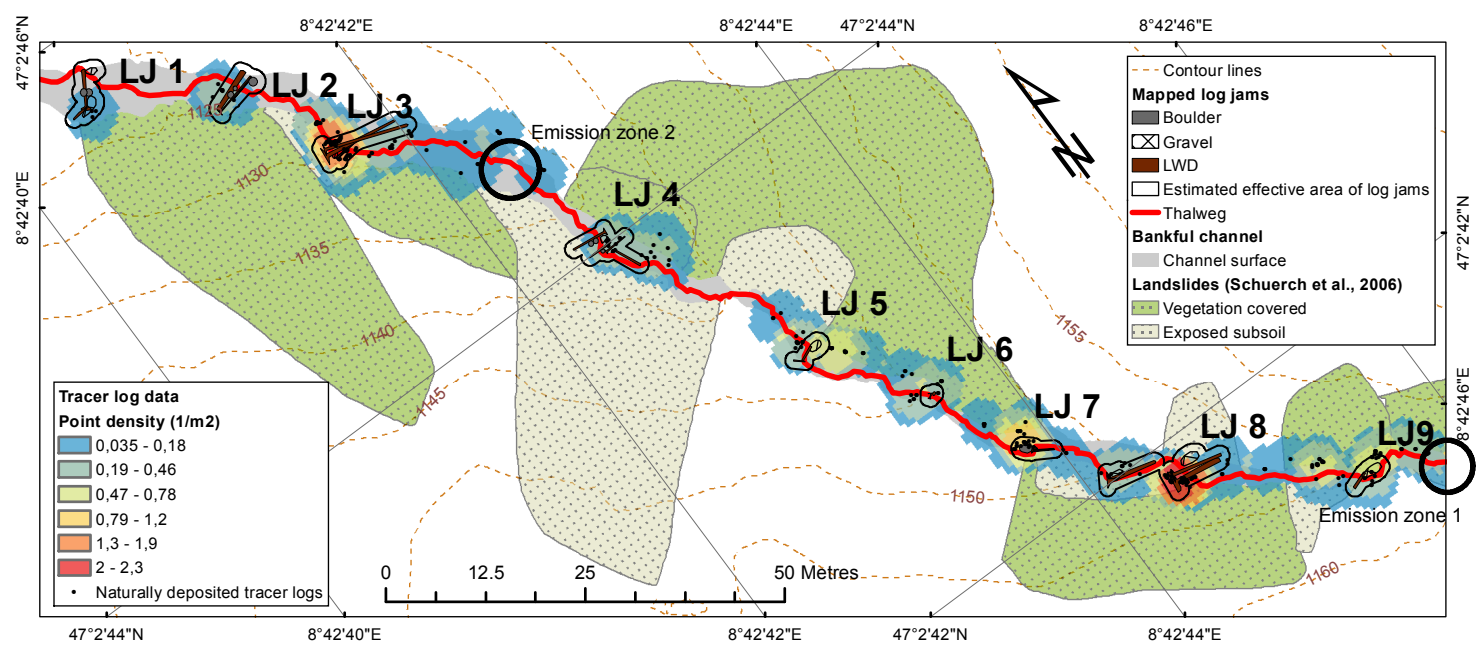

Figure 4. Map of the study reach including visualizations of the $\log$ jams (LJ1 to LJ9, cf. Table 3) and the point densities of naturally deposited tracer logs. The effective area of LJs was estimated by adding a buffer of $1 \mathrm{~m}$ around the mapped LJ perimeter to account for survey inaccuracy.
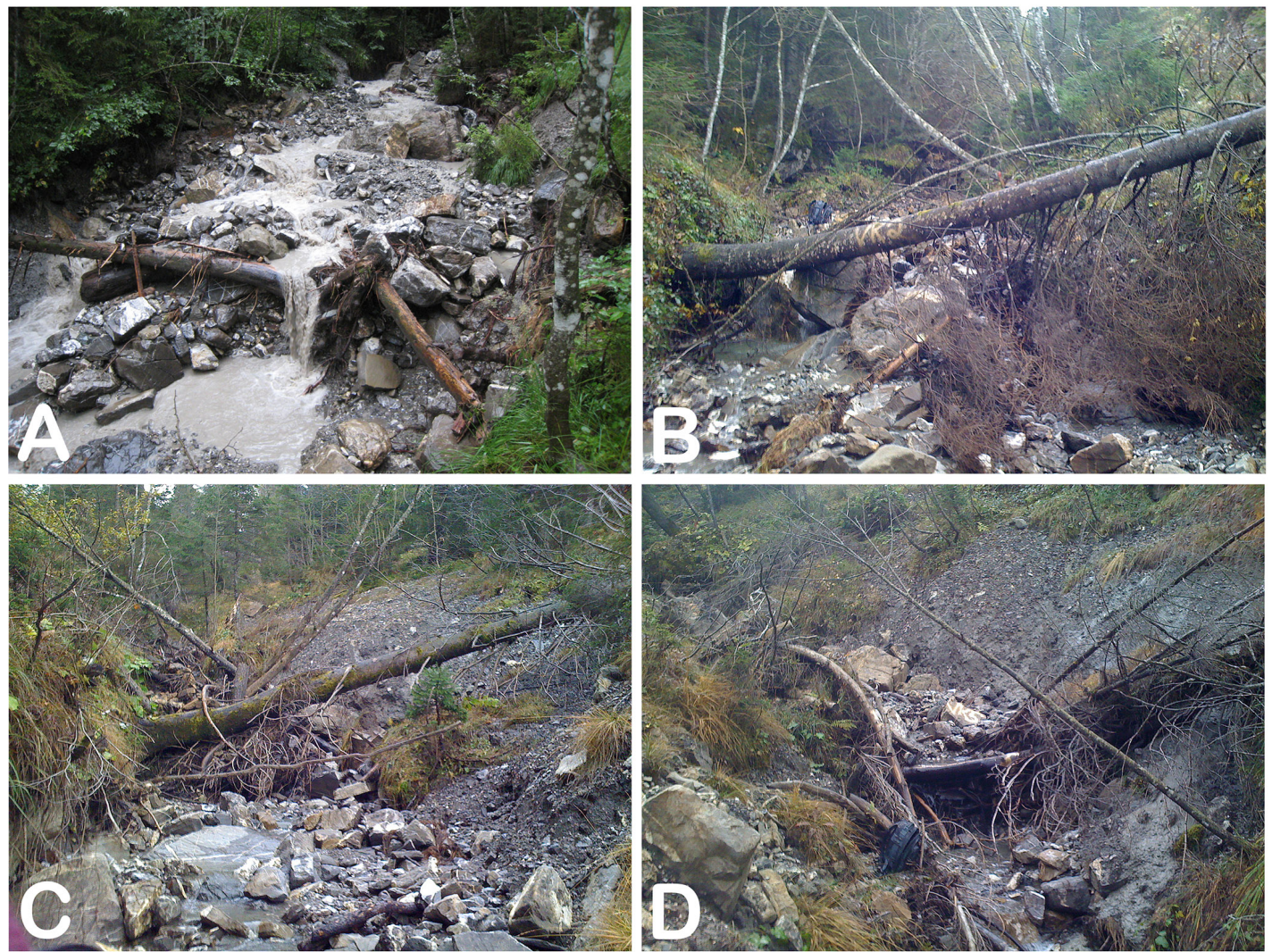

Figure 5. Four example log jams in the study reach: LJ1 (a), LJ2 (b), LJ4 (c), LJ5 (d). For the positions and characteristics of the jams within the study reach refer to Fig. 4 and Table 3. Each log jam shows a distinct key piece blocking the channel, thereby being responsible for the upstream accumulation of woody debris and sediment.

years (Turowski et al., 2009), and we hypothesize that the observed LWD input in 2008 and 2011 is a consequence of the exceptional discharge events in 2007 and 2010, respectively, rather than being attributed to the current years' flood history. The stream bank side from which the new jam-forming logs presumably originate (as indicated by the side of their 


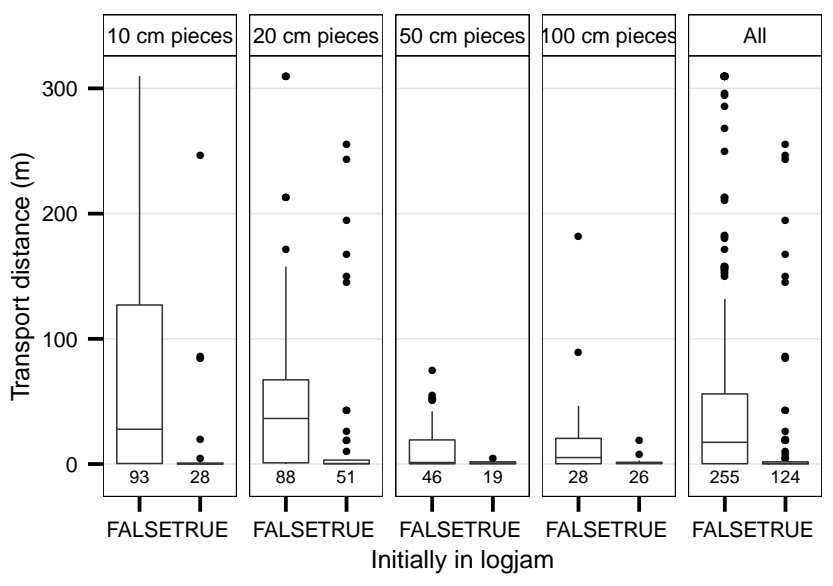

Figure 6. Transport distances of the tracer logs that were situated within or outside a log jam before the discharge event. The data are presented for four different length classes. The number below the plot gives the number of data points used in the analysis. The differences in median transport distances between pieces inside and outside log jams in the 10 and $20 \mathrm{~cm}$ classes, as well as for all pieces combined, are highly significant.

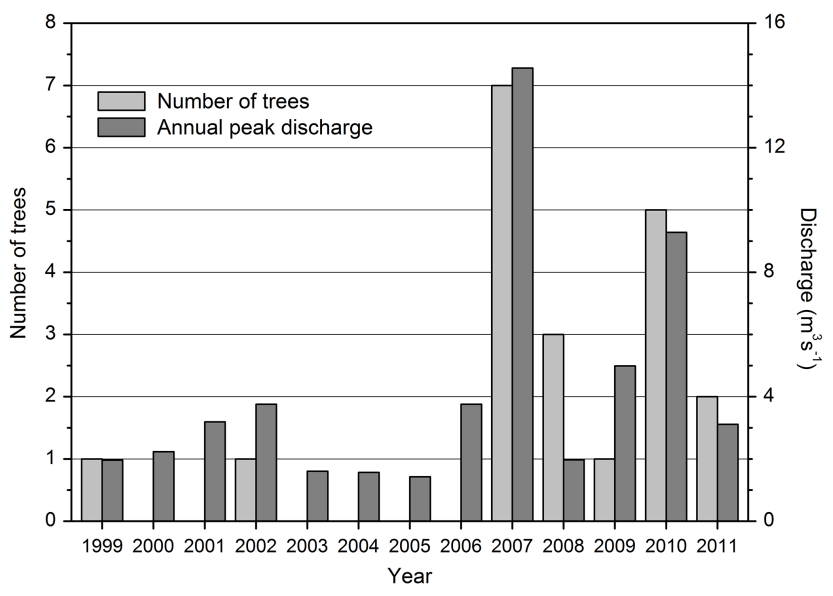

Figure 7. Histogram of kill dates of trees stored within the nine log jams (cf. Table 3) in the study reach of the Erlenbach (light grey) and annual peak discharges in the respective years (dark grey).

root wads) spatially concurs with zones of active landslides along the channel bed (Fig. 4, cf. Schuerch et al., 2006). It should be noted that exceptional discharge events produced by heavy rainfall can be accompanied by an input of forest litter and duff from upland areas, which also has an influence on CPOM dynamics of a stream.

\subsection{Conceptual model}

The observations made at the Erlenbach stream allow formulation of a four-stage conceptual model for log jam dynamics and associated wood transport in steep mountain streams (Fig. 8). In steep streams, log jams form along the channel
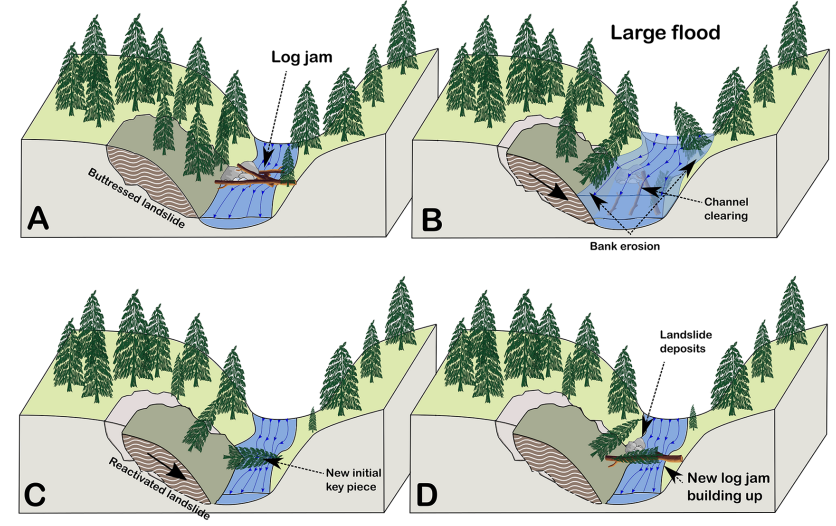

Figure 8. Visualization of the four-stage conceptual model for log jam dynamics and wood transport in steep headwater streams. (a) Mountain stream channel after longer period without large flood. A log jam obstructs the channel, reduces the stream's sediment and CPOM transport capacity and stabilizes the stream's banks. (b) An exceptional flood event mobilizes the log jam and evacuates all wood pieces from the channel. (c) The mobilization of log and boulder steps as well as bank erosion during the flood event reactivate hillslope processes and lead to the introduction of a new key piece to the channel. (d) The new key piece initiates a new cycle of log jam dynamics.

around large initial logs, and mainly consist of trees that died in the immediate vicinity of the jam. After a period of no exceptional flood events, these logs obstruct the stream, reduce flow velocities and transport capacity of sediment and wood particles, but also stabilize adjacent banks (Fig. 8a). These log jams represent temporary storage sites and grow with time, thereby collecting an increasing amount of material including both organic matter and sediment. Exceptional discharge events, by contrast, as observed in 2007 and 2010 at the Erlenbach, fulfill a dual role. They may mobilize log jams and evacuate even the coarsest pieces from the reach, thus cleaning the channel and increasing connectivity (Fig. 8b). At the same time, the mobilization of steps formed by boulders and log jams as well as bank erosion activates hillslope processes (Fig. 8c) and thereby intensifies the coupling between channel and hillslopes (cf. Molnar et al., 2010). Subsequently, new logs are recruited into the channel, allowing for the formation of new jams around key pieces and the initiation of a new cycle (Fig. 8d).

The conceptual model proposed herein can well explain the steep rating relationship between CPOM transport rates and discharge in many streams (e.g., Turowski et al., 2013a). Log jams act as storage sites for CPOM pieces, collecting the steady supply of small- and medium-sized pieces to release them during large flood events, when the jams are at least partly mobilized. Log jam mobilization will release large amounts of CPOM for transport, which may in turn affect the stability of jams further downstream and result in a runaway effect due the increase in process intensity. 
Analogous to the impact of log jams on CPOM transport, it seems that there is also a similar influence of log jams on the transport of clastic sediments. Wedges of sediment appear to build up between the log jams (also storing organic matter) and the export rating curve of bedload shows a similarly steep increase with discharge as the CPOM export rating curve (cf. Turowski et al., 2009). It seems likely that considerable volumes of CPOM are stored in those sediment wedges and are mobilized and exported from the catchment after log jam destruction.

\subsection{Comparison with larger fluvial systems}

The conceptual model described earlier (Fig. 8) refers to LWD dynamics in low-order steep mountain streams, and here we compare it to models that have been developed for larger streams (e.g., Hyatt and Naiman, 2001; O'Connor et al., 2003; Wohl, 2013). In larger fluvial systems, supply and evacuation of logs is generally assumed to occur more or less continuously and it has not been possible to assess how the recent discharge history may lead to a more episodic supply and removal of LWD, probably due to the unavailability of discharge measurements. This implies that residence times show a broad distribution and that large deviations from the mean in the residence times of individual logs can frequently be observed. For example, for the Queets River (USA), Hyatt and Naiman (2001) reported a mean residence time of around 30 years, but the time since recruitment of individual logs ranged from 1 year to more than 1400 years. By contrast, we observe that most logs in the Erlenbach have been recruited during or shortly after the last exceptional discharge events, therefore yielding a much narrower age distribution of logs with well-defined peaks corresponding to years with large floods.

From a mechanistic perspective, the difference in behavior of large and small streams can be explained by wood transport processes. Various log jam types have been described (Abbe and Montgomery, 2003). At the Erlenbach, eight out of nine $\log$ jams were log steps, a jam type typical for streams with small drainage areas in which at least one key piece has a length larger than the channel width (Abbe and Montgomery, 2003). Pieces of LWD longer than the channel width are known to be rarely transported (Bilby and Ward, 1989; Nakamura and Swanson, 1993), and LWD moves farther and more frequently in larger streams (Lienkaemper and Swanson, 1987; Wohl, 2013). Thus, log steps can be expected to be less mobile than other jam types typical for larger streams. Again, this highlights the role of exceptional events for CPOM export in streams like the Erlenbach.

\subsection{Four-end-member model}

An important precondition for our conceptual model appears to be the debris flow (in-)activity of the respective stream as there are no signs of debris flows at the Erlenbach and sedi-

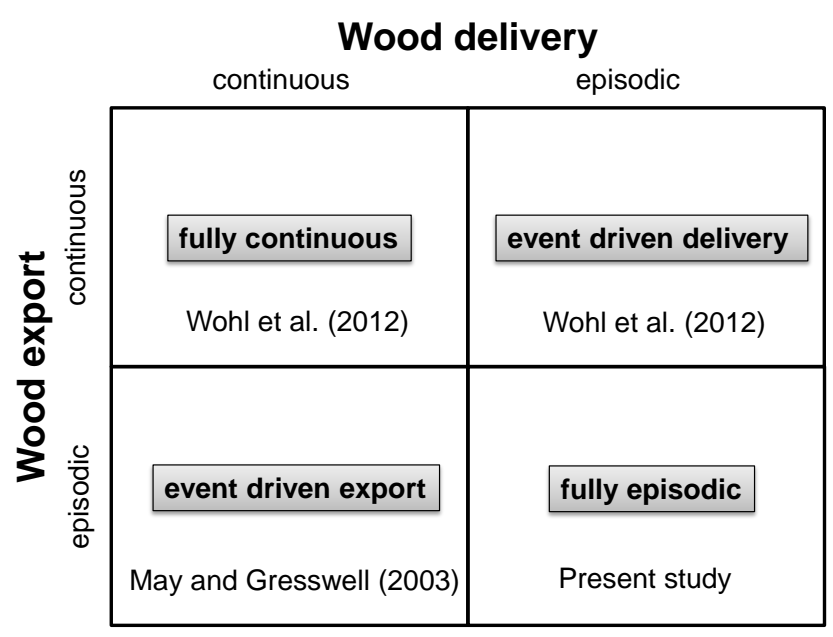

Figure 9. Four-end-member model of LWD dynamics based on wood delivery and export. The models of Wohl et al. (2012), May and Gresswell (2003) and of the present study are placed in a temporal continuum of LWD delivery and export.

ment is only fluvially transported (Turowski et al., 2009). In a conceptual model developed by May and Gresswell (2003) for similar order streams in the Oregon Coast Range (USA), the evacuation of the stream channel is driven by debris flows rather than by fluvial transport. Also, the input of LWD in their model is assumed to be temporally constant and directly related to the time since the last debris flow event. In contrast, we propose that LWD input occurs mostly during and shortly after extreme events.

Wohl et al. (2012) formulated a two-end-member model for neotropical low-order headwater streams based on the dominating delivery process of LWD. It features a steadystate and an episodic end-member. The steady-state endmember is characterized by individual tree delivery and gradual export of specific pieces. The dominating processes of the episodic end-member are an event-based recruitment and gradual but more accentuated export.

To merge the existing models, we not only consider the temporal characteristics of LWD delivery, but also put emphasis on the export characteristics. By placing the four models in a temporal continuum of LWD input and export (Fig. 9), we define a new concept including four endmembers, consisting of an event-driven delivery end-member (Wohl et al., 2012), an event-driven export end-member (May and Gresswell, 2003), a fully continuous end-member (Wohl et al., 2012) and a fully episodic end-member (this study). By considering the continuity of both input and export processes, the log jam dynamics of fluvial systems with different characteristics can be viewed within a unified framework. 


\section{Conclusions}

Extreme discharge events play a key role in CPOM dynamics in steep mountains streams. These events mobilize LWD in the channel, thereby favoring the evacuation of CPOM material stored in log jams out of the catchment. By intensifying channel-hillslope coupling, extreme discharge events also facilitate the recruitment of new logs into the channel.

These dynamics explain the steep rating relationship observed between CPOM transport rates and discharge in various streams. The residence times derived from tree ring chronologies of large logs stored in Erlenbach jams varied between 1 and 13 years at the time of measurement, and most $\operatorname{logs}$ entered the channel during or in the aftermath of the last two exceptional floods. The CPOM dynamics observed at the Erlenbach thus stand in stark contrast to the more continuous transport of LWD in larger streams, where wood piece residence times have a wide distribution.

The conceptual model of $\log$ jam dynamics and wood transport formulated herein can be combined with existing conceptual models to form a four-end-member model. The four end-members have event-driven delivery or event-driven export, or are fully episodic or fully continuous. By combining log jam dynamics from different field settings as described in the literature with the observed behavior of the Erlenbach, the conceptual model provides a unified framework for the interpretation of log jam dynamics in fluvial systems of different size.

Acknowledgements. We thank A. Pöhlmann, C. Schär, K. Steiner, and A. Stahel of the Mountain Torrents research group at WSL as well as T. Schneider, M. Conder, and M. Fischer of the Institute of Geography at the University of Bern for interesting discussions and comprehensive assistance in the field. The help and advice on dendrochronological methods of D. Trappmann, J. Ballesteros, and A. Sorg is acknowledged. Two anonymous reviewers and associate editor R. Hilton provided constructive comments on the discussion paper. This study was supported by the WSL and the University of Bern.

Edited by: R. Hilton

\section{References}

Abbe, T. B. and Montgomery, D. R.: Patterns and processes of wood debris accumulation in the Queets river basin, Washington, Geomorphology, 51, 81-107, 2003.

Badoux, A., Turowski, J. M., Mao, L., Mathys, N., and Rickenmann, D.: Rainfall intensity-duration thresholds for bedload transport initiation in small Alpine watersheds, Nat. Hazards Earth Syst. Sci., 12, 3091-3108, doi:10.5194/nhess-12-30912012, 2012.

Beckman, N. D. and Wohl, E.: Carbon storage in mountainous headwater streams: The role of old-growth forest and logjams, Water Res., 50, 2376-2393, 2014.
Bilby, R. E. and Likens, G. E.: Importance of organic debris dams in the structure and function of stream ecosystems, Ecology, 61, 1107-1113, 1980.

Bilby, R. E. and Ward, J. W.: Changes in characteristics and function of woody debris with increasing size of streams in Western Washington, T. Am. Fish. Soc., 118, 368-378, 1989.

Bormann, F. H., Likens, G. E., and Eaton, J. S.: Biotic regulation of particulate and solution losses from a forest ecosystem, Bioscience, 19, 600-610, 1969.

Burch, H.: Ein Rückblick auf die hydrologische Forschung der WSL im Alptal: Beiträge zur Hydrologie der Schweiz, 35, 1833, 1994.

Comiti, F., Andreoli, A., Lenzi, M. A., and Mao, L.: Spatial density and characteristics of woody debris in five mountain rivers of the Dolomites (Italian Alps), Geomorphology, 78, 44-63, 2006.

Fisher, S. G. and Likens, G. E.: Energy flow in Bear Brook, New Hampshire - integrative approach to stream ecosystem metabolism, Ecol. Monogr., 43, 421-439, 1973.

Gryc, V., Vavrčik, H., and Horn, K.: Density of juvenile and mature wood of selected coniferous species, J. Forest Sci., 57, 123-130, 2011.

Harmon, M. E., Franklin, J. F., Swanson, F. J., Sollins, P., Gregory, S. V., Lattin, J. D., Anderson, N. H., Cline, S. P., Aumen, N. G., Sedell, J. R., Lienkaemper, G. W., Cromack, K., and Cummins, K. W.: Ecology of coarse woody debris in temperate ecosystems, Adv. Ecol. Res., 15, 132-302, 1986.

Hyatt, T. L. and Naiman, R. J.: The residence time of large woody debris in the Queets River, Washington, USA, Ecol. Appl., 11, 191-202, 2001.

Iroumé, A., Mao, L., Andreoli, A., Ulloa, H., and Ardiles, M. P.: Large wood mobility processes in low-order Chilean river channels, Geomorphology, 228, 681-693, 2015.

Kaennel, M. and Schweingruber, F. H.: Multilingual glossary of dendrochronology, Bern, 1995

Kraft, C. E., Warren, D. R., and Keeton, W. S.: Identifying the spatial pattern of wood distribution in northeastern North American streams, Geomorphology, 135, 1-7, 2011.

Lamarre, H., MacVicar, B. J., and Roy, A. G.: Using Passive Integrated Transponder (PIT) tags to investigate sediment transport in gravel-bed rivers, J. Sediment. Res., 75, 736-741, 2005.

Lienkaemper, G. W. and Swanson, F. J.: Dynamics of large woody debris in streams in old-growth douglas-fir forests, Can. J. Forest Res., 17, 150-156, 1987.

Lombardi, F., Cherubini, P., Lasserre, B., Tognetti, R., and Marchetti, M.: Tree rings used to assess time since death of deadwood of different decay classes in beech and silver fir forests in the central Apennines (Molise, Italy), Can. J. Forest Res., 38, 821-833, 2008.

MacVicar, B. J., Piégay, H., Henderson, A., Comiti, F., Oberlin, C., and Pecorari, E.: Quantifying the temporal dynamics of wood in large rivers: field trials of wood surveying, dating, tracking, and monitoring techniques, Earth Surf. Proc. Land., 34, 2031-2046, 2009.

May, C. L. and Gresswell, R. E.: Large wood recruitment and redistribution in headwater streams in the southern Oregon Coast Range, USA, Can. J. Forest Res., 33, 1352-1362, 2003.

Molnar, P., Densmore, A. L., McArdell, B. W., Turowski, J. M., and Burlando, P.: Analysis of changes in the step-pool morphology 
and channel profile of a steep mountain stream following a large flood, Geomorphology, 124, 85-94, 2010.

Naiman, R. J. and Sedell, J. R.: Benthic organic-matter as a function of stream order in Oregon: Archiv für Hydrobiologie, 87, 404422, 1979

Nakamura, F. and Swanson, F. J.: Effects of Coarse Woody Debris on Morphology and Sediment Storage of a Mountain Stream System in Western Oregon, Earth Surf. Proc. Land., 18, 43-61, 1993.

O’Connor, J. E., Jones, M. A., and Haluska, T. L.: Flood plain and channel dynamics of the Quinault and Queets Rivers, Washington, USA, Geomorphology, 51, 31-59, 2003.

Ravazzolo, D., Mao, L., Picco, L., and Lenzi, M. A.: Tracking log displacement during floods in the Tagliamento River using RFID and GPS tracker devices, Geomorphology, 228, 226-233, 2015.

Rickenmann, D. and McArdell, B. W.: Continuous measurement of sediment transport in the Erlenbach stream using piezoelectric bedload impact sensors, Earth Surf. Proc. Land., 32, 1362-1378, 2007.

Rickenmann, D., Turowski, J. M., Fritschi, B., Klaiber, A., and Ludwig, A.: Bedload transport measurements at the Erlenbach stream with geophones and automated basket samplers, Earth Surf. Proc. Land., 37, 1000-1011, 2012.

Ruiz-Villanueva, V., Díez-Herrero, A., Ballesteros, J. A., and Bodoque, J. M.: Potential large woody debris recruitment due to landslides, bank erosion and floods in mountain basins: a quantitative estimation approach, River Res. Appl., 30, 81-97, 2014.

Schenk, E. R., Moulin, B., Hupp, C. R., and Richter, J. M.: Large wood budget and transport dynamics on a large river using radio telemetry, Earth Surf. Proc. Land., 39, 487-498, 2013.

Schneider, J. M., Hegglin, R., Meier, S., Turowski, J. M., Nitsche, M., and Rickenmann, D.: Studying sediment transport in mountain rivers by mobile and stationary RFID antennas, in: Proceedings of the 5th International Conference on Fluvial Hydraulics, Bundesanstalt für Wasserbau, Braunschweig, 17231730, 2010.

Schneider, J. M., Turowski, J. M., Rickenmann, D., Hegglin, R., Arrigo, S., Mao, L., and Kirchner, J. W.: Scaling relationships between bed load volumes, transport distances, and stream power in steep mountain channels, J. Geophys. Res.-Earth, 119, 533549,2014

Schuerch, P., Densmore, A. L., McArdell, B. W., and Molnar, P.: The influence of landsliding on sediment supply and channel change in a steep mountain catchment, Geomorphology, 78, 222$235,2006$.
Smith, J. C., Galy, A., Hovius, N., Tye, A. M., Turowski, J. M., and Schleppi, P.: Runoff-driven export of particulate organic carbon from soil in temperate forested uplands, Earth Surf. Proc. Land., 365, 198-208, 2013.

Stoffel, M. and Corona, C.: Dendroecological Dating of Geomorphic Disturbance in Trees, Tree-Ring Research, 70, 3-20, 2014.

Turowski, J. M., Yager, E. M., Badoux, A., Rickenmann, D., and Molnar, P.: The impact of exceptional events on erosion, bedload transport and channel stability in a step-pool channel, Earth Surf. Proc. Land., 34, 1661-1673, 2009.

Turowski, J. M., Badoux, A., and Rickenmann, D.: Start and end of bedload transport in gravel-bed streams, Geophys. Res. Lett., 38, L04401, doi:10.1029/2010GL046558, 2011.

Turowski, J. M., Badoux, A., Bunte, K., Rickli, C., Federspiel, N., and Jochner, M.: The mass distribution of coarse particulate organic matter exported from an Alpine headwater stream, Earth Surf. Dynam., 1, 1-11, doi:10.5194/esurf-1-1-2013, 2013 a.

Turowski, J. M., Badoux, A., Leuzinger, J., and Hegglin, R.: Large floods, alluvial overprint, and bedrock erosion, Earth Surf. Proc. Land., 38, 947-958, 2013b.

Wallace, J. B., Whiles, M. R., Eggert, S., Cuffney, T. F., Lugthart, G. H., and Chung, K.: Long-term dynamics of coarse particulate organic-matter in three Appalachian mountain streams, J. N. Am. Benthol. Soc., 14, 217-232, 1995.

Warren, D. R., Kraft, C. E., Keeton, W. S., Nunery, J. S., and Likens, G. E.: Dynamics of wood recruitment in streams of the northeastern US, Forest Ecol. Manage., 258, 804-813, 2009.

Webster, J. R., Benfield, E. F., Ehrman, T. P., Schaeffer, M. A., Tank, J. L., Hutchens, J. J., and D'angelo, D. J.: What happens to allochthonous material that falls into streams? A synthesis of new and published information from Coweeta, Freshw. Biol., 41, 687-705, 1999.

Wohl, E.: Floodplains and wood, Earth-Sci. Rev., 123, 194-212, 2013.

Wohl, E. and Beckman, N.: Controls on the longitudinal distribution of channel-spanning logjams in the Colorado Front Range, USA, River Res. Appl., 30, 112-131, 2012.

Wohl, E., Bolton, S., Cadol, D., Comiti, F., Goode, J. R., and Mao, L.: A two end-member model of wood dynamics in headwater neotropical rivers, J. Hydrol., 462-463, 67-76, 2012.

Wohl, E. and Jaeger, K.: A conceptual model for the longitudinal distribution of wood in mountain streams, Earth Surf. Proc. Land., 34, 329-344, doi:10.1002/esp.1722, 2009.

Zimmermann, A. E., Church, M., and Hassan, M. A.: Identification of steps and pools from stream longitudinal profile data, Geomorphology, 102, 395-406, 2008. 